University of Nebraska - Lincoln

DigitalCommons@University of Nebraska - Lincoln

Faculty Publications, Department of Psychology

Psychology, Department of

2006

\title{
Possible association between response inhibition and a variant in the brain-expressed tryptophan hydroxylase-2 gene
}

\author{
Scott F. Stoltenberg \\ University of Nebraska-Lincoln, sstoltenberg2@unl.edu \\ Jennifer M. Glass \\ University of Michigan \\ Steven T. Chermack \\ University of Michigan \\ Heather A. Flynn \\ University of Michigan \\ Sheng Li \\ University of Michigan \\ See next page for additional authors
}

Follow this and additional works at: https://digitalcommons.unl.edu/psychfacpub

Part of the Psychiatry and Psychology Commons

Stoltenberg, Scott F.; Glass, Jennifer M.; Chermack, Steven T.; Flynn, Heather A.; Li, Sheng; Weston, Margaret E.; and Burmeister, Margit, "Possible association between response inhibition and a variant in the brain-expressed tryptophan hydroxylase-2 gene" (2006). Faculty Publications, Department of Psychology. 474.

https://digitalcommons.unl.edu/psychfacpub/474

This Article is brought to you for free and open access by the Psychology, Department of at DigitalCommons@University of Nebraska - Lincoln. It has been accepted for inclusion in Faculty Publications, Department of Psychology by an authorized administrator of DigitalCommons@University of Nebraska - Lincoln. 


\section{Authors}

Scott F. Stoltenberg, Jennifer M. Glass, Steven T. Chermack, Heather A. Flynn, Sheng Li, Margaret E. Weston, and Margit Burmeister 


\title{
Possible association between response inhibition and a variant in the brain-expressed tryptophan hydroxylase-2 gene
}

\author{
Scott F. Stoltenberg, ${ }^{1,2}$ Jennifer M. Glass, ${ }^{2}$ Steven T. Chermack, ${ }^{2}$ Heather A. Flynn, ${ }^{2}$ \\ Sheng Li, ${ }^{3}$ Margaret E.Weston, ${ }^{2}$ and Margit Burmeister ${ }^{3}$ \\ I. Department of Psychology, Black Hills State University, Spearfish, South Dakota \\ 2.Addiction Research Center, Department of Psychiatry, University of Michigan, Ann Arbor, Michigan \\ 3. Mental Health Research Institute, Department of Psychiatry, University of Michigan, Ann Arbor, Michigan \\ Corresponding author - S. F. Stoltenberg
}

\begin{abstract}
The ability to inhibit a response is an important component of normal behavioral control and is an aspect of psychopathology when diminished. Converging evidence implicates the serotonergic neurotransmitter system in response inhibition circuitry.

Objectives - The present study examined potential associations between serotonergic genetic markers and response inhibition as indexed by Stop Task performance.

Methods - College-age participants $(N=199)$ completed self-report questionnaires, the computerized Stop Task, and donated buccal cells for genetic analyses. Statistics were analyzed by ANOVA.

Results - Stop Signal reaction time was not associated with allelic variation at a monoamine oxidase A promoter length polymorphism or a serotonin IB terminal autoreceptor polymorphism (G86IC). An intronic genetic marker of the neuronal tryptophan hydroxylase-2 (the rate-limiting enzyme for serotonin biosynthesis) gene, however, was associated with the Stop Signal reaction time. Individuals homozygous for the T variant at an intron-8 polymorphism had the longest Stop Signal reaction time (i.e. greater impulsivity, $P=0.0 \mathrm{I}$ ), and this effect was stronger in males $(P=0.01)$ than in females $(P=0.10)$.

Conclusions - A genotype at an intron-8 tryptophan hydroxylase- 2 polymorphism was associated with response inhibition as indexed by the Stop Task. These results, if replicated, would implicate dorsal raphe serotonin neurons in response inhibition. It may be that individuals with the T/T genotype may have reduced tryptophan hydroxylase-2 function and correspondingly lower central serotonin levels; however, further investigation of the reported association is required.
\end{abstract}

Keywords: serotonin, association study, impulsivity, stop task

The ability to inhibit responses is critical for normal behavioral flexibility (Logan et al., 1984) and to direct behavior to achieve long-term goals (Nigg, 2000). Deficits in response inhibition are associated with several psychiatric disorders, such as attention deficit/hyperactivity disorder (ADHD) (Schachar et al., 2000), and substance abuse (Vogel-Sprott et al., 2001; Fillmore and Rush, 2002).

The serotonin system influences impulsivity in human beings and in other animals (Linnoila et al., 1983; Westergaard et al., 2003; Winstanley et al., 2003; Clarke et al., 2004). Impulsive aggression decreases with the administration of drugs that raise serotonin levels (New et al., 2004), and impulsivity is increased by diets that reduce serotonin levels (Crean et al., 2002; Walderhaug et al., 2002). Studies have reported associations between serotonin system gene variants and ADHD (Hawi et al., 2002; Sheehan et al., 2005), impulsivity and suicidality in major depressive disorder (Arango et al., 2001;
Mann et al., 2001) and antisocial alcoholism (Hill et al., 2002). Response inhibition has been localized to the prefrontal cortex (Aron and Poldrack, 2005), which is innervated by serotonergic neurons. No studies to date have reported using a laboratory measure of response inhibition to examine potential associations with serotonergic genetic markers.

The University of Michigan Medical School Institutional Review Board approved this study. One hundred and ninety-nine participants (111 females, 88 males) (a) responded to advertisements offering $\$ 50$ for 90 minutes of anonymous participation, (b) completed self-report questionnaires, (c) completed the Stop Task, and (d) donated buccal cells. Their age ranged from 18 to 38 years $($ mean $=20.8)$. Data for these analyses included the 67.8\% $(N=135)$ self-identified as "White, not of Hispanic origin" (to control for population stratification). For multivariate analyses, only cases without missing data were included (final $N=109$, 67 females; 42 males). 
For the Stop Task, an " $\mathrm{X}$ " or an "O" is displayed on a computer screen, and instructions are to respond rapidly by pressing one of two keys, depending on the visual stimulus. On $25 \%$ of trials, a tone [Stop Signal (SS)] sounds after the $\mathrm{X}$ or $\mathrm{O}$ appears, indicating that participants should withhold responding. The delay between the visual stimulus and the SS starts at $250 \mathrm{~ms}$ and is dynamically adjusted depending on the participant's response. If a response was made, the delay for the next SS decreased by $50 \mathrm{~ms}$ (easier to inhibit); if no response was made, the delay for the next SS was similarly increased (harder to inhibit). This delay yields a response inhibition rate of approximately $50 \%$ and provides reliable estimates of StopRT (Band et al., 2003). To calculate StopRT (an index of inhibitory control), average SS delay is subtracted from average GoRT. StopRT is related to normal variations in impulsivity (Logan et al., 1997) and to differences in behavioral inhibition in various psychopathologies (Nigg, 1999; Fillmore and Rush, 2002; Nigg et al., 2002, 2004). Thus, the StopRT is useful for understanding both normal and impaired executive function.

In all, there were 64 practice trials, followed by four blocks of 80 trials. We averaged the final four blocks unless, during a block, a participant inhibited responding on less than $30 \%$ or more than $70 \%$ of trials, which was taken as a failure to follow instructions. Data from only those "bad" blocks were discarded and the participant's mean scores were based on the remaining blocks (Nigg, 1999). Data from 15 participants were discarded in this manner.

Average GoRT on trials without an SS was $483.40 \mathrm{~ms}$. Males (459.24 ms) were faster, on average, than females $\left[506.31 \mathrm{~ms} ; F_{(1,107)}=4.43, P=0.04\right]$. Average StopRT was 225.39 ms (males, $232.18 \mathrm{~ms}$; females, $221.13 \mathrm{~ms}$, NS).

DNA extracted from buccal cells (Puregene Kit, Gentra Systems, Minneapolis, Minnesota, USA) was used in polymerase chain reactions (PCRs) carried out in 20 $\mathrm{ml}$ volume, using $2 \mu \mathrm{l}$ genomic DNA, $200 \mu \mathrm{M}$ of each $\mathrm{dNTP}$, and $1.5 \mathrm{U}$ Taq polymerase. PCR products were separated by electrophoresis in agarose gels and visualized by ethidium bromide under ultraviolet light, except for the MAOA variable number tandem repeat (VNTR), which was separated by denaturing polyacrylamide gel electrophoresis.

Serotonin $1 \mathrm{~B}$ terminal autoreceptor $\left(5-\mathrm{HTR}_{1 \mathrm{~B}}\right)(6 \mathrm{q} 13)$ is a $G$ protein-linked receptor that appears to play a role in aggression, substance abuse and obsessive-compulsive disorder (Ramboz et al., 1996; Rocha et al., 1998; Veenstra-Vanderweele et al., 2000). These primers were used to assay the 5-HT $1 \mathrm{~B}$ G861C polymorphism: 5HT1B5 5' GAA ACA GAC GCC CAA CAG GAC; 5HT1B6 5'
CCA GAA ACC GCG AAA GAA GAT (Lappalainen et al., 1995). The amplification was carried out with 6.6 pmol of each primer in buffer [TNK (Tris, ammonium, potassium): $50,9.0 \mathrm{pH}, 1.5 \mathrm{mM} \mathrm{MgCl}{ }_{2}$ ] for 30 cycles $\left(1 \mathrm{~min}\right.$ at $90^{\circ} \mathrm{C}, 2 \mathrm{~min}$ at $60^{\circ} \mathrm{C}$, and $3 \mathrm{~min}$ at $72^{\circ} \mathrm{C}$ ), and products were digested using $2.5 \mathrm{U}$ HincII (New England Biolabs, Ipswich, Massachusetts, USA).

MAOA is an enzyme that inactivates biogenic amines throughout the body (Xp11.23). Variants in the MAO promoter region and in the gene have been associated with impulsivity and aggression (Manuck et al., 2000). For the VNTR polymorphism in the monoamine oxidase A (MAOA) gene promoter region PCR, the following primers were used: MaoaPT1 5' ACA GCC TGA CCG TGG AGA AG and MaoaPB1 5' GAA CGG ACG CTC CAT TCG GA. Amplification was carried out with 20 pmol of each primer in buffer $\left[167 \mathrm{mM}\left(\mathrm{NH}_{4}\right)_{2} \mathrm{SO}_{4}, 670\right.$ $\mathrm{mM}$ Tris pH 8.8, $20 \mathrm{mM} \mathrm{MgCl}_{2}, 100 \mathrm{mM}$ 2-mercaptoethanol, $10 \mathrm{mg} / \mathrm{ml}$ bovine serum albumin], $1.2 \mathrm{M}$ betaine, and $1 \%$ dimethylsulfoxide for 35 cycles $\left(1 \mathrm{~min}\right.$ at $94^{\circ} \mathrm{C}, 2$ min at $55^{\circ} \mathrm{C}$, and $3 \mathrm{~min}$ at $72^{\circ} \mathrm{C}$, with a final extension of $10 \mathrm{~min}$ at $72^{\circ} \mathrm{C}$ ).

Tryptophan hydroxylase is the rate-limiting enzyme in serotonin synthesis. Association of variants in an intron and in the promoter of tryptophan hydroxylase (TPH) have been found with impulsive-aggressive behavior, suicidality, ADHD, and depression-related traits (Nielsen et al., 1998; Tsai et al., 1999; Turecki et al., 2001; Sheehan et al., 2005). Recently, tryptophan hydroxylase2 (TPH2) (12q21.1) was found to be the main gene encoding TPH in the brain (Walther and Bader, 2003). For the intron-8 polymorphism (rs1386483) of TPH2 PCR, the following primers were designed: TPH2f-5' GCT GGC TCT GAA CGT GTA TTT TG and TPH2r-5' TTT

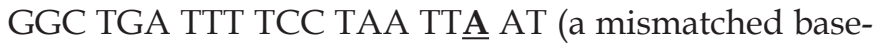
pair $\underline{\text { A generates a restriction site). Amplification was }}$ carried out with 20 pmol of each primer in buffer (TNK: $50 \mathrm{pH}$ 9.0, $1.5 \mathrm{mM} \mathrm{MgCl}$ ) for 35 cycles $\left(1 \mathrm{~min}\right.$ at $95^{\circ} \mathrm{C}, 2$ min at $53^{\circ} \mathrm{C}$, and $3 \mathrm{~min}$ at $72^{\circ} \mathrm{C}$ ), and products were digested using 5.0 U SspI (New England Biolabs).

Allele frequencies were calculated by pooling across sex, except for MAOA, which is located on the X chromosome and therefore was examined separately by sex. For 5- $\mathrm{HT}_{1 \mathrm{~B}} \mathrm{G} 861 \mathrm{C}, \mathrm{G}=0.79, \mathrm{C}=0.21(\mathrm{~N}=52)$; for MAOA VNTR, males $1=0.48,3=0.52(N=29)$, females $0=0.01$, $1=0.36,3=0.63,4=0.01(N=52)$; for TPH2, $\mathrm{T}=0.34, \mathrm{C}$ $=0.66(N=119)$. The markers were in Hardy-Weinberg equilibrium. Sample sizes varied because of difficulties in amplifying some samples.

ANOVAs with Sex and Genotype as fixed effects and StopRT as the dependent variable were not significant for $5-\mathrm{HT}_{1 \mathrm{~B}}$ and MAOA. For TPH2 (see Figure 1), both 


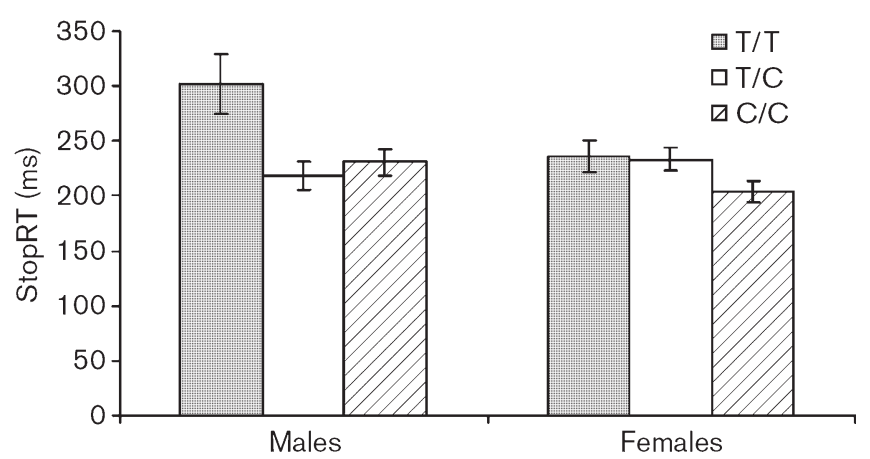

Figure I. Mean Stop Signal reaction time (StopRT) (with standard errors) for males and females across the TPH2 genotype. Greater values for StopRT indicate higher levels of impulsivity. The model explained $12.3 \%$ of the variance in StopRT. Post-hoc analyses revealed an association between Genotype and StopRT among the males $\left[F_{(2,}\right.$ 39) $=4.85, P=0.01]$ with the T/T genotype associated with the longest StopRT (greater impulsivity). Among the females, there was a trend for the $\mathrm{C} / \mathrm{C}$ genotype to be associated with the shortest StopRT $\left[F_{(2,64)}=2.40, P=0.10\right]$.

Sex $\left[F_{(1,109)}=4.14, P=0.04\right]$ and Genotype $\left[F_{(2,109)}=4.53\right.$, $P=0.01]$ were associated with StopRT and there was a significant Sex $\times$ Genotype interaction $\left[F_{(2,109)}=3.34, P\right.$ $=0.04]$.

TPH2 is the rate-limiting enzyme for serotonin biosynthesis expressed in the dorsal raphe nucleus and is an important candidate gene for several psychiatric disorders. For example, TPH2 variants are associated with ADHD (Sheehan et al., 2005), major depressive disorder (Zhang et al., 2005), suicide (Zill et al., 2004), and repetitive behaviors in autism (Coon et al., 2005).

We found that a TPH2 polymorphism was associated with response inhibition. Specifically, males with the T/ $\mathrm{T}$ genotype had the longest StopRTs, and among females there was a trend in that direction. The TPH2 association with response inhibition remains statistically significant, after correction for multiple testing. We speculate that males with the $\mathrm{T} / \mathrm{T}$ genotype have reduced neural $\mathrm{TPH}$ function and lower central serotonin levels.

This finding adds to the converging evidence that TPH2 is associated with impulsivity. Our result, however, like all first reports on genetic association studies, needs to be replicated before generalization.

The intronic SNP is more than $20 \mathrm{~kb}$ downstream of the previous exon, and $3.7 \mathrm{~kb}$ before the next exon. HAPMAP ( http://www.hapmap.org ) inspection shows that this SNP is in linkage disequilibrium with SNPs downstream, including some that are close to the exon 9 splice site, and it thus might affect splicing. In addition, it is intriguing that a functional, protein-coding TPH2 variant (which is not in HAPMAP) was recently reported to be associated with depression and SSRI response (Zhang et al., 2005). It is worth noting that substantial linkage disequilibrium has been found along the TPH2 gene (Zill et al., 2004). Future research may address whether the $\mathrm{T}$ variant of the intron- 8 polymorphism in $\mathrm{TPH} 2$ that we found associated with StopRT is in linkage disequilibrium with the novel reduced function TPH2 variant. Our finding appears to be the first reported association between the brain-expressed TPH2 gene and a laboratory measure of impulsivity.

\section{References}

Arango V, Underwood MD, Boldrini M, Tamir H, Kassir SA, Hsiung $S$, et al. (200I). Serotonin IA receptors, serotonin transporter binding and serotonin transporter mRNA expression in the brainstem of depressed suicide victims. Neuropsychopharmacology 25:892-903.

Aron AR, Poldrack RA (2005). The cognitive neuroscience of response inhibition: Relevance for genetic research in attentiondeficit/hyperactivity disorder. Biol Psychiatry 57: I 285-1 292.

Band GP,Van Der Molen MW, Logan GD (2003). Horse-race model simulations of the stop-signal procedure. Acta Psychol (Amst) I | 2: 105-142.

Clarke HF, Dalley JW, Crofts HS, Robbins TW, Roberts AC (2004). Cognitive inflexibility after prefrontal serotonin depletion. Science 304:878-880.

Coon H, Dunn D, Lainhart J, Miller J, Hamil C, Battaglia A, et al. (2005). Possible association between autism and variants in the brainexpressed tryptophan hydroxylase gene (TPH2). Am J Med Genet B Neuropsychiatr Genet 135:42-46.

Crean J, Richards JB, De Wit H (2002). Effect of tryptophan depletion on impulsive behavior in men with or without a family history of alcoholism. Behav Brain Res 136:349-357.

Fillmore MT, Rush CR (2002). Impaired inhibitory control of behavior in chronic cocaine users. Drug Alcohol Depend 66:265-273.

Hawi Z, Dring M, Kirley A, Foley D, Kent L, Craddock N, et al. (2002). Serotonergic system and attention deficit hyperactivity disorder (ADHD): a potential susceptibility locus at the 5-HT(IB) receptor gene in 273 nuclear families from a multi-centre sample. Mol Psychiatry 7:718-725.

Hill EM, Stoltenberg SF, Bullard KH, Li S, Zucker RA, Burmeister M (2002). Antisocial alcoholism and serotonin-related polymorphisms:Association tests. Psychiatr Genet I 2:143-I53.

Lappalainen J, Dean M, Charbonneau L, Virkkunen M, Linnoila M, Goldman D (1995). Mapping of the serotonin 5-HTID beta autoreceptor gene on chromosome 6 and direct analysis for sequence variants. Am J Med Genet 60:|57-16I.

Linnoila M, Virkkunen M, Scheinin M, Nuutila A, Rimon R, Goodwin FK (1983). Low cerebrospinal fluid 5-hydroxyindoleacetic acid concentration differentiates impulsive from nonimpulsive violent behavior. Life Sci 33:2609-26I4.

Logan GD, Cowan WB, Davis KA (1984). On the ability to inhibit simple and choice reaction time responses: $A$ model and a method.J Exp Psychol Hum Percept Perform 10:276-29I. 
Logan GD, Schachar R, Tannock R (1997). Impulsivity and inhibitory control. Psychol Sci 8:60-64.

Mann JJ, Brent DA, Arango V (200I). The neurobiology and genetics of suicide and attempted suicide: $A$ focus on the serotonergic system. Neuropsychopharmacology 24:467-477.

Manuck SB, Flory JD, Ferrell RE, Mann JJ, Muldoon MF (2000). A regulatory polymorphism of the monoamine oxidase-A gene may be associated with variability in aggression, impulsivity, and central nervous system serotonergic responsivity. Psychiatry Res 95:9-23.

New AS, Buchsbaum MS, Hazlett EA, Goodman M, Koenigsberg HW, Lo J, et al. (2004). Fluoxetine increases relative metabolic rate in prefrontal cortex in impulsive aggression. Psychopharmacology (Berlin) I 76:45I-458.

Nielsen DA, Virkkunen M, Lappalainen J, Eggert M, Brown GL, Long JC, et al. (1998). A tryptophan hydroxylase gene marker for suicidality and alcoholism. Arch Gen Psychiatry 55:593-602.

Nigg JT (1999). The ADHD response-inhibition deficit as measured by the stop task: Replication with DSM-IV combined type, extension, and qualification.J Abnorm Child Psychol 27:393-402.

Nigg JT (2000). On inhibition/disinhibition in developmental psychopathology:Views from cognitive and personality psychology and a working inhibition taxonomy. Psychol Bull I 26:220-246.

Nigg JT, Blaskey LG, Huang-Pollock CL, Rappley MD (2002). Neuropsychological executive functions and DSM-IV ADHD subtypes.J Am Acad Child Adolesc Psychiatry 41:59-66.

Nigg JT, Glass JM, Wong MM, Poon E, Jester JM, Fitzgerald HE, et al. (2004). Neuropsychological executive functioning in children at elevated risk for alcoholism: Findings in early adolescence. J Abnorm Psychol I 13:302-3|4.

Ramboz S, Saudou F, Amara DA, Belzung C, Segu L, Misslin R, et al. (1996). 5-HTIB receptor knock out - Behavioral consequences. Behav Brain Res 73:305-312.

Rocha BA, Scearce-Levie K, Lucas JJ, Hiroi N, Castanon N, Crabbe JC, et al. (1998). Increased vulnerability to cocaine in mice lacking the serotonin- IB receptor. Nature 393: I75-178.

Schachar R, Mota VL, Logan GD, Tannock R, Klim P (2000). Confirmation of an inhibitory control deficit in attention-deficit/hyperactivity disorder. J Abnorm Child Psychol 28:227-235.
Sheehan K, Lowe N, Kirley A, Mullins C, Fitzgerald M, Gill M, et al. (2005). Tryptophan hydroxylase 2 (TPH2) gene variants associated with ADHD. Mol Psychiatry.

Tsai SJ, Hong CJ, Wang YC (1999). Tryptophan hydroxylase gene polymorphism (A218C) and suicidal behaviors. Neuroreport 10:3773-3775.

Turecki G, Zhu Z, Tzenova J, Lesage A, Seguin M, Tousignant M, et al. (200I).TPH and suicidal behavior:A study in suicide completers. Mol Psychiatry 6:98-102.

Veenstra-Vanderweele J, Anderson GM, Cook EH Jr. (2000). Pharmacogenetics and the serotonin system: Initial studies and future directions. Eur J Pharmacol 41 0:165-18I.

Vogel-Sprott M, Easdon C, Fillmore M, Finn P, Justus A (200I). Alcohol and behavioral control: Cognitive and neural mechanisms. Alcohol Clin Exp Res 25:117-121.

Walderhaug E, Lunde H, Nordvik JE, Landro NI, Refsum H, Magnusson A (2002). Lowering of serotonin by rapid tryptophan depletion increases impulsiveness in normal individuals. Psychopharmacology (Berlin) I 64:385-39I.

Walther DJ, Bader M (2003). A unique central tryptophan hydroxylase isoform. Biochem Pharmacol 66:1673-1680.

Westergaard GC, Suomi SJ, Chavanne TJ, Houser L, Hurley A, Cleveland A, et al. (2003). Physiological correlates of aggression and impulsivity in free-ranging female primates. Neuropsychopharmacology 28: 1045-1055.

Winstanley CA, Dalley JW, Theobald DE, Robbins TW (2003). Global 5-HT depletion attenuates the ability of amphetamine to decrease impulsive choice on a delay-discounting task in rats. Psychopharmacology (Berlin) I70:320-33I.

Zhang X, Gainetdinov RR, Beaulieu JM, Sotnikova TD, Burch LH, Williams RB, et al. (2005). Loss-of-function mutation in tryptophan hydroxylase-2 identified in unipolar major depression. Neuron 45: II-16.

Zill P, Buttner A, Eisenmenger W, Moller HJ, Bondy B, Ackenheil M (2004). Single nucleotide polymorphism and haplotype analysis of a novel tryptophan hydroxylase isoform (TPH2) gene in suicide victims. Biol Psychiatry 56:581-586. 